\title{
PRAXIS AND THE INTERNATIONAL (HUMAN RIGHTS) LAW SCHOLAR: TOWARD THE INTENSIFICATION OF TWAILIAN DRAMATURGY ${ }^{+}$
}

\author{
Obiora Chinedu Okafor*
}

The article critically reflects on the role of the TWAILian international (human rights) law scholar in the socio-economic and political struggles which take place outside the academe; focusing, for the most part, on our role as scholars in advancing struggles in favour of subaltern Third World peoples from within or in concert with international institutions and various kinds of what I will refer to in this paper as "on-the-ground" activist groups (such as social movements and NGOs). The article begins by examining some of the various ideas and conceptions of praxis, so as to be clear from the outset as to the sense in which that key term is used in this context. The question of the ends or goals for which we do praxis is also discussed at this point. The discussion then moves on to the important question of what it means to enact TWAIL praxis and to do so within or in relation to international institutions or "on-the-ground" groups, and a conceptual/normative framework for such activity is offered. The paper then focuses on a relatively brief analysis of some of the experiences that the author has had as a TWAILian international (human rights) law scholar who has also been closely engaged in some way with international institutions and on-the-ground groups. Following this, a reflection on the promise and perils of such close engagement with this kind of praxis is offered. The article ends with some concluding remarks.

As used in this paper, the expression "TWAILian dramaturgy" is adapted from the concept of "critical dramaturgy" which refers to "a concern for the ways in which human drama, very broadly defined [as for instance human drama within or in relation to social movements, NGOs, and the $\mathrm{UN}$ ] can be used to augment, rather than distort or destroy, human social existence." See TR Young, The Drama of Social Life: Essays in Post-Modern Social Psychology (New Brunswick, NJ: Transaction Publishers, 1990) at 13. A TWAILian dramaturgy ought therefore to be animated and framed by a significant degree of concern for the ways in which such international or related human drama can be used to attain the broad TWAIL goals of significantly augmenting or improving the socio-political and economic conditions of Third World peoples.

* York Research Chair in International and Transnational Legal Studies at the Osgoode Hall Law School, York University, Toronto, Canada; Chairperson, the United Nations Human Rights Council Advisory Committee, Geneva, Switzerland; and most recently the Gani Fawehinmi Distinguished Chair in Human Rights Law at the Nigerian Institute of Advanced Legal Studies, Abuja, Nigeria. PhD, LLM (University of British Columbia, Vancouver, Canada); LLM, LLB (Hons) (University of Nigeria, Enugu Campus, Nigeria. I am grateful to Serwaah Frimpong, Olohirere Musa and John Mastrangelo, JD students at the Osgoode Hall Law School, for their excellent research assistance. I should also thank the participants at both the Conference on Third World Approaches to International Law held at the American University in Cairo, Egypt, in February 2015, and the follow-up TWAIL Publication Workshop held in Windsor, Canada, in June 2015, for their comments and suggestions. In the last regard, Jeff Noonan, Sujith Xavier, Usha Natarajan, John Reynolds, and Hani Sayed deserve special mention. I specially dedicate this keynote paper to my ever patient and loving family (Atugonza, Ojiako, Mbabazi and Kosi), without whose solid and unflinching support this paper would not have seen the light of day. 
Dans cet article, on fait une réflexion critique sur le rôle du chercheur TWAILien en droit international spécialisé dans les droits de la personne dans les luttes socioéconomiques et politiques qui se déroulent à l'extérieur des milieux universitaires; on se polarise en majeure partie sur le rôle que jouent les universitaires dans l'impulsion des combats en faveur des peuples subalternes du tiers monde, de l'intérieur ou de concert avec des institutions internationales et divers types de ce que l'auteur appelle groupes militants "sus-terrains » (comme les mouvements sociaux et les ONG). L'article commence par un examen de certaines des idées et conceptions diverses de l'action pour établir clairement dès le départ le sens dans lequel ce terme clé est utilisé dans ce contexte. La question des fins ou des buts de l'action fait également l'objet du débat à ce point. L'article porte ensuite sur une analyse relativement brève de quelques expériences vécues par l'auteur en tant que chercheur TWAILien en droit international spécialisé dans les droits de la personne qui a également été associé de près d'une quelconque manière aux institutions internationales et aux groupes «sus-terrains». L'auteur propose ensuite une réflexion sur la promesse et les dangers d'une participation aussi intime à ce genre d'action. $L$ 'article se termine par quelques commentaires.

"And this from Upandru:

Screen your bedchamber thoughts

with sun glasses

who could jump your eye,

your mind window

And I said:

The Prophet only the poet

And he said: Logistics.

(Which is what poetry is)...

And he said to the ram: Disarm

And I said:

Except by rooting,

Who could pluck yam tubers from their base?"

And there are here

the errors of the rendering...

- Chris Okigbo ${ }^{1}$

1 See Christopher Okigbo, Collected Poems (London: Heinemann, 1986) at 25. 


\section{INTRODUCTION}

I must begin this keynote address by expressing my deep gratitude to the organizers for their sharp vision and huge effort in making this historic conference possible. I have watched from afar as you conceived the idea for this conference, sketched its outlines, painted it in bold relief, and animated it into life. Your seamless straddling of its conception and execution is a wonderful example of the best kind of TWAIL praxis, at least in the academic sense and setting.

I must also indicate how every pleased I am to be here - on this historic occasion, in a land (Egypt) that has made so much "acknowledged history." For one, I find myself ensconced among my colleagues in TWAIL scholarship who are also comrades in TWAIL praxis. Few environments could be more inviting and pleasing for a scholar whose academic career can be described as, more or less, a life in TWAIL. For when not "Trailing TWAIL,"1 as many increasingly do, I have tended to do TWAIL. ${ }^{2}$ It is as exhilarating and pleasing that the self-identified TWAIL cohort among whom I circulate at this conference is impressively large and diverse. This, to my mind, is a testament to how rapidly and robustly the TWAIL approach has resonated and the movement has grown, and a living monument to its acute vision and thought. This expansion and deepening of the movement is remarkable, given that as we have been told by some of the epic historians of TWAIL's development "in the contemporary period," notwithstanding its much longer pedigree, the current TWAIL renaissance only began in earnest in the mid-1990s when the TWAIL vision statement was adopted at the Harvard TWAIL conference. ${ }^{3}$ This was a key moment in the development of TWAIL as a scholarly and political movement. ${ }^{4}$ We have definitely come a long way since then in terms of the growth of the movement and the passage of time. In this vein it is instructive that, as Gathii has noted, TWAIL courses are now taught far and wide and a booming and diverse TWAIL literature now exists around the world (including a large number of Ph.D. and Masters theses). ${ }^{5}$

As importantly, we have also literally come a long way in the sense of geographical distance from the North American locations in which contemporary TWAIL has tended to be centred. This is another reason that I am really excited to be present at this gathering, the very first TWAIL conference to be held in the global South, the part of our world in which the global injustices that concern TWAILers the most are most acute and in which socio-economic and political ferment is relatively more heated and intense at this moment in human history. This is one good reason why this conference has made significant symbolic and material history.

1 See John D Haskell, "TRAIL-ing TWAIL: Arguments and Blind Spots in Third World Approaches to International Law" (2014) 27 Can JL \& Jur 383.

2 My conception of "doing TWAIL" (which appears to be widely shared among TWAILers) is explained at length in Obiora Chinedu Okafor, "Newness, Imperialism and International Legal Reform in our Time: A TWAIL Perspective" (2005) 43 Osgoode Hall LJ 171 [Okafor, "Newness"].

3 See Karin Mickelson, "Taking Stock of TWAIL Histories" (2008) 10 Intl Community L Rev 355 at 356-358 [Mickelson, "Taking Stock"]; and James Thuo Gathii, "TWAIL: A Brief History of its Origins, its Decentralized Network, and a Tentative Bibliography" (2011) 3 Trade, L \& Development 26 at 27.

4 See Mickelson, "Taking Stock" ibid at 356-358.

5 See Gathii, supra note 4 at 33, 49-64. 
The conference also excites me tremendously because of the broad thematic that defines it, the overarching problematique on which it focuses squarely, i.e., "on praxis and the intellectual," or on "the role of the intellectual in the political and/or socio-economic struggles which go on beyond the academe." This is a thematic that some in the movement, e.g., B.S. Chimni, ${ }^{6}$ have for long hinted that we ought to focus much more on over the years. The relationships among TWAILers (on the one hand) and politicians, diplomats, activists, civil servants, peasant movements, civil society, etc. (on the other hand), is as important to TWAIL as it has been under-studied and under-enacted. ${ }^{7}$

As importantly, I must also intimate that it is a great honour and privilege to offer this keynote on the enchanting and vast continent on which I was born and spent my formative years, in whose bowels my umbilical cord is buried, and to which I will be forever joined in flesh and spirit. To laterally invert a portion of Antony Anghie's now famous 1993 essay entitled "the heart of my home," this place is "the home of my heart"! ${ }^{8}$ These are some of the reasons for my great excitement at participating in this historic conference.

I cannot, however, conclude these introductory remarks without acknowledging and thanking all those whose writings, teachings, and mentorship have consciously or unconsciously, but profoundly, shaped my intellectual development, ideas and work as a TWAILer. In particular, I am simply humbled and thrilled to share the keynote slot at this conference with one of these scholars, the legendary Professor and Judge, Georges Abi-Saab.

In line with the overall thematic of this conference and our usual TWAILian effort "to take stock and look to the future" at such conferences, the theme of this keynote paper is "Praxis and the International (Human Rights) Law Scholar: Toward the Intensification of TWAILian Dramaturgy". As such, the paper will critically reflect on the role of the TWAILian international (human rights) law scholar in the socio-economic and political struggles which take place outside the academe focusing, for the most part, on our role as scholars in advancing struggles in favour of subaltern Third World peoples from within or in concert with international institutions and various kinds of what I will refer to in this paper as "on-theground" activist groups (such as social movements and NGOs).

As such, the paper is organized into seven segments, this introduction included. Section II examines the ideas and conceptions of praxis, so as to be clear from the outset as to the sense in which that key term is used in this paper. The question of the ends or goals for which we do praxis is also discussed there. In section III, the important question of what it means to enact TWAIL praxis and to do so within or in relation to international institutions or "on-the-ground" groups is raised and discussed by way of offering a conceptual/normative framework for such activity. Section IV focuses on a relatively brief

6 See BS Chimni, "Third World Approaches to International Law: A Manifesto" in Antony Anghie et al, eds, The Third World and International Order: Law, Politics and Globalization (Leiden: Martinus Nijhoff, 2003) at 48 [Chimni, "Manifesto"].

7 The organizers raised some of these questions in the "Call for Papers and Panel Proposals" they issued in early 2014 (on file with the author) ["Call for Papers"]. See also "Conference Program - Third World Approaches to International Law: On Praxis and the Intellectual" (February 12, 2015), online:

$<$ http://www.uwindsor.ca/twail2015/sites/uwindsor.ca.twail2015/files/twail_program_feb_8.pdf> at 1 [“Conference Program"].

8 See Antony Anghie, “"The Heart of My Home': Colonialism, Environmental Damage and the Nauru Case” (1993) 34:2 Harv Intl LJ 445. 
analysis of some of the experiences that I have had as a TWAILian international (human rights) law scholar who has also been closely engaged in some way with international institutions and on-theground groups. Section V is devoted to a reflection on the promise of such close engagement, while section VI focuses on the perils of engaging in this kind of praxis. Thereafter, the paper ends in section VII with some concluding remarks.

\section{THE IDEAS AND CONCEPTIONS OF PRAXIS}

As Vincent Mosco and a number of other scholars (such as Upendra Baxi) have noted, praxis is an idea with deep roots in the history of philosophy and one which has found several paths to social, political and other studies, including through Marxian theory, the Frankfurt School of critical thought, and the "action-research" tradition best embodied in sociology, and anticolonial scholarship. Originating in the ancient Greek, it achieved some prominence in the work of Aristotle (who saw the goal of praxis as action). ${ }^{10}$ Thereafter, it came to occupy a central place in the works of philosophers such as Hegel (who both separated and united praxis and theory), Kant (who saw full reason as the product of the unification of practical reason and theory), and Marx (who always insisted that philosophy be made practical). ${ }^{11}$ Much later on, scholars of the Frankfurt School, especially Jurgen Habermas, treated the concept of social praxis as constituted by both work (i.e., purposive rational action) and communicative action (interaction). ${ }^{12}$ And so there are more or less multiple and differing conceptions of praxis in the relevant literature sets.

However, most of the contemporary usages of the term praxis embed deeply within them some notion of the inherent unity of thought and action, and of the "inseparability of theory and practice"13 - or at least of the critical desirability of such a unity and inseparability. ${ }^{14}$ This is certainly the case with almost all Marxian and neo-Marxian approaches. Exemplifying this tradition, Claire Cutler pithily reminds us that "the philosophy of praxis postulates the immanent unity of material and ideational conditions in a historical process of becoming." 15 And Herbert Marcuse teaches us that to engage in praxis "is not to tread on alien ground, external to the theory, for the theory itself is already a practical one; praxis does

$9 \quad$ See Vincent Mosco, The Political Economy of Communication (London: Sage, 2009) at 34. See also Upendra Baxi, The Future of Human Rights (Delhi: Oxford University Press, 2006) at 83 [Baxi, Future of Human Rights].

10 Ibid.

11 Ibid at 34-35.

12 Ibid at 35. See also Jurgen Habermas, Legitimation Crisis (Boston: Beacon Press, 1975).

13 See E Jouannet, "Koskenniemi: A Critical Introduction" in Martti Koskenniemi, The Politics of International Law (Oxford: Hart Publishing, 2011) 1 at 3.

14 See Rebekah L Fox \& Joshua J Frye, "Tensions of Praxis: A New Taxonomy of Social Movements" (2010) 4:4 Environmental Communication 422; Stephen Kemmis, "Research for Praxis: Knowing Doing" (2010) 18:1 Pedagogy, Culture \& Society 9; and Gail Furman, "Social Justice Leadership as Praxis: Developing Capacities Through Preparation Programs" (2012) 48:2 Educational Administration Q 191.

15 See A Claire Cutler, "Toward a Radical Political Economy Critique of Transnational Economic Law" in Susan Marks, ed, International Law on the Left (Cambridge: Cambridge University Press, 2008) 199 at 216. 
not only come at the end, but is already present in the beginning of the theory." 16 In the same vein, Mosco has correctly noted that:

Praxis guides a theory of knowledge to view knowing as the ongoing product of theory and practice. It rejects as partial those epistemologies which conclude that truth [or to put it more carefully, knowledge] can only result from contemplation. Rather it grows out of the mutual constitution of conception and execution. ${ }^{17}$

It is in this last sense of the mutual constitution of conception and execution, of the unity (or unification) of theory-imbued action and action-imbued theory, that the concept of praxis is used in this paper. Some have even explained this concept as "thoughtful doing." 18

Yet, whatever the sense in which the term praxis is understood and used, the critical question remains, praxis for what, and to what end? The relevant literature sets are heavily populated by leftleaning answers to this question. For example, Furman views praxis as involving the continual, dynamic interaction among knowledge acquisition, deep reflection, and action with the purpose of transformation and liberation in the service of social justice. ${ }^{19}$ And Claire Cutler argues that the philosophy of praxis directs attention to identifying and transforming the social forces that give rise to laws that create and sustain a world characterized by increasing inequalities. ${ }^{20}$ While TWAILers will, of course, tend to identify with these progressive visions of the goals to which our own praxis ought to be directed, it is important to point out that the insights of scholars such as Antonio Gramsci and Upendra Baxi would suggest that praxis, on its own, and without more, might not be necessarily directed at attaining social justice ends. In this connection, Gramsci's famous warning about the dangers that can be posed by some organic intellectuals who are schooled in both theory and practice leaps quickly to mind. ${ }^{21}$ And Baxi's mild anxiety about the critical difference between a politics of human rights and a politics for human rights is highly instructive. ${ }^{22}$ For, if our praxis (as TWAILers) merely furthers the politics of human rights without the desired ideological moorings and underpinnings, how useful would it be from our perspective, and what's the point, really?

And so, against this background, how should we think about TWAIL praxis (including in the international human rights area that I focus on in this paper)? How might we enact TWAIL praxis in pursuit of the kinds of global social justice goals that all of us desire?

16 See Cutler, ibid at 219; and Herbert Marcuse, Studies in Critical Philosophy, translated by Joris De Bres (London: New Left Books, 1973) at 5.

17 Mosco, supra note 10 at 35 [Emphasis added].

18 See Martha J Dede, "The Praxis Journal: Integrating Theory and Practice” (2002) 8:4 J of Public Affairs Education 275.

19 See Furman, supra note 15 at 203.

20 See Cutler, supra note 16.

21 See Mosco, supra note 10 at 36.

22 See Baxi, supra note 10 at 83. 


\section{ENACTING TWAIL PRAXIS: TOWARD A CONCEPTUAL FRAMEWORK}

Given the conception of praxis that is preferred in this paper, it seems clear that there is a sense in which TWAIL itself is already praxis. For one, TWAIL is avowedly a scholarly and political movement, with broadly unifying "political and transformative commitments." ${ }^{, 23}$ Indeed, as I have noted in another context:

...TWAIL scholars (or "TWAILers") are solidly united by a shared ethical commitment to the intellectual and practical struggle to expose, reform, or even retrench the features of the international system that help create or maintain the generally unequal, unfair, or unjust global order. ${ }^{24}$

And Pooja Parmar has correctly noted that the lives and struggles of Third World peoples are central to TWAIL. ${ }^{25}$ Secondly, many of the things that many TWAILers already do can add up to a form of praxis: for example, who we choose to cite in our writings; who and what we choose to teach in our courses; who we chose to read the most in the context of scarcity of time; which graduate students we choose to take on; and which directions we choose to encourage these students to take. All of these are crucial forms and instantiations of praxis, albeit only in the limited academic setting. The academe is thus in and of itself a site and habitat of praxis as a life form.

Yet, although this specific form of praxis within the academe cannot be neatly or tightly separated from any other form of praxis that we can and do enact, it is not the form of praxis that the theme of this conference mostly envisages. Rather, the current thematic focuses - at least for the most part - on the roles of TWAILers in broader political life and on our relationships to more general societal structures, i.e., our relationships as (mostly) international (human rights) law intellectuals "with politicians, activists, advocates, revolutionaries, civil servants, soldiers, artists, writers, union representatives, civil society leaders, peasant movements, and so on. ${ }^{, 26}$ This conference's thematic thus envisages TWAIL praxis within or in relation to other habitats (institutional, popular, and so on).

It should be noted, however, that as crucial and timely as the questions raised by this thematic are, this is not the first time they have been at least hinted at in TWAIL circles, howsoever tangentially, obliquely or inchoately. Indeed, it is a question that has agitated the minds of many a contemporary TWAILer from the very beginning. Even the vision statement that formally inaugurated the contemporary TWAIL epoch would appear to have contemplated this kind of "praxis beyond the academe" (albeit only implicitly) when it committed TWAILers to the task of "disseminating" their critical insights. ${ }^{27}$ And as I have already noted, B.S. Chimni has persistently called on us over the years to "project an alternative vision of international law (presumably, including to the world beyond the

23 See "Call for Papers" and "Conference Program," supra note 8. See also Okafor, "Newness", supra note 3; Mickelson, "Taking Stock", supra note 4 at 357; and Luis Eslava \& Sundhya Pahuja, "Between Resistance and Reform: TWAIL and the Universality of International Law" (2011) 3 Trade, L \& Development 103 at 109.

See Okafor, "Newness", supra note 3 at 176-177 [Emphasis added].

See Pooja Parmar, "TWAIL: An Epistemological Inquiry” (2008) 10 Intl Community L Rev 363.

26 See "Call for Papers," supra note 8.

27 For a re-statement and analysis of this vision statement, see Mickelson, “Taking Stock", supra note 4 at 357-358. 
academe)." 28 And the recognition of the importance of paying some attention to praxis has long populated the TWAIL literature (e.g., Upendra Baxi's deep concern with struggles and social action, Makau Mutua's push for the transformation of human rights NGOs, Rajagopal's abiding focus on "resistance," and Eslava and Pahuja's call on us to "get down and dirty" and "delve into the everyday life of international law"). ${ }^{29}$ In most of these cases, this recognition has crystallized, at least in part, from the previous or ongoing active engagement of the relevant scholar(s) with either activists, international institutions, or both.

More recently, though, more direct calls have been made for TWAILers to more intensively engage international institutions and on-the-ground groups in order to more effectively "disseminate" and "project" their alternative visions of international law and global society. For instance, following the broad thrust and implications of the work done by Chimni et al., Opeoluwa Badaru has called on TWAILers to deal more squarely and directly with questions like: "how can TWAIL work with social movements" and "how can the visions of TWAILers be further incorporated into the work of social movements on the ground?" "30 To these one may add the question: how can TWAIL insights be disseminated and projected more robustly to and within international institutions, diplomatic delegations, military formations, NGOs, social movements, and other bodies (both international and domestic)? Implicit in these calls is the suggestion that it may be beneficial in some way for TWAILers to work with and/or within bodies and groups.

Against this background, the main question that is raised is: what would it mean for us to enact TWAIL praxis in relation to, or from within, the specific habitats in which international and domestic civil servants, politicians, activists, advocates, revolutionaries, civil servants, soldiers, artists, writers, union representatives, civil society leaders, and peasant movements, are to be more readily found, accessed and fed a diet rich in TWAIL nutrients? More specifically, for the purposes of this paper, what would it mean for a TWAILian international (human rights) law scholar to enact a praxis of closely engaging, taking root within, spreading her/his tentacles and ideas around, and ideationally/practically impacting, such bodies and groups?

From my own reflections on TWAIL and other critical internationalist literature, it seems to me that to effectively enact TWAIL praxis in these non-academic habitats/environments, we would need to be guided by the following conceptual/normative framework (constituted by commitments, insights, resources, sensibilities and concerns).

\section{A Commitment to a Broadly TWAILian Style and Substance in our Work:}

28 See Chimni, "Manifesto", supra note 7 at 48 (emphasis added).

29 See Baxi, supra note 10 at 20-21, 66-67. See also Makau Mutua, Human Rights: A Political and Cultural Critique (Philadelphia: University of Pennsylvania Press, 2002); Balakrishnan Rajagopal, International Law from Below: Development, Social Movements, and Third World Resistance (Cambridge: Cambridge University Press, 2003) [Rajagopal, International Law]; and Eslava \& Pahuja, supra note 24 at 123.

30 See Opeoluwa Adetoro Badaru, "Examining the Utility of Third World Approaches to International Law for International Human Rights Law" (2008) 10:4 Intl Community L Rev 379 at 385-386. 
As fundamental as this is to the enactment of TWAIL praxis, since the TWAIL literature already brims and overflows with such commitment, little needs to be said about it here. ${ }^{31}$

2. A Significant Measure of Theoretical/Conceptual Clarity as to the Goals of TWAIL: Since the TWAIL literature is broadly consistent in this regard, such clarity will usually not be all that difficult to achieve. The devil will, however, be in some of the nitty-gritty details regarding very specific TWAIL end goals. For example, given important critiques of the International Criminal Court [ICC] for its current geo-stationary orbit over only the African continent, ${ }^{32}$ should TWAIL work toward the abolition of the ICC, or simply its reform? And, in the short term, should TWAIL oppose or support the clause in the new Protocol on the establishment of an international criminal law chamber within the proposed African Court of Justice and Human/Peoples' Rights, which grants temporary transactional immunity from prosecution to heads of state while they are in office $?^{33}$ Despite all of us agreeing that we should stand in opposition to all the international norms and institutions that facilitate and maintain the domination, impoverishment and immiseration of Third World peoples, TWAILers may disagree as to what the concrete goals of TWAIL ought to be in these specific, concrete, circumstances.

\section{The Recognition that there is Room in such Non-academic Praxis for both the "Situated Participant" and the "External Observer"; and there is not Necessarily a Radical Separation between these Two Postures:}

Here, I rely in part on Martti Koskenniemi's theoretical reflections on his own close engagements with and within the UN Security Council. ${ }^{34}$ Borrowing, perhaps, from the earlier work of McDougal and Laswell (the founders of the so-called New Haven School of International Legal Theory who famously argued that "[i]n few of the historic emphases have the standpoint and purposes of the scholarly observer been clearly distinguished from those of the more active participants in the social processes being subjected to inquiry"), Koskenniemi makes an important distinction between the "situated participant" (who tends to have an "internal or engaged perspective" on such institutions) and the "external observer" (who tends not to routinely possess that

31 See Okafor, "Newness", supra note 3; Gathii, supra note 3; Makau Mutua, "What is TWAIL?" (2000) 94 American Society of International Law Proceedings 31; and Parmar, supra note 26.

32 See Obiora Chinedu Okafor \& Uchechukwu Ngwaba, "The International Criminal Court as a 'Transitional Justice' Mechanism in Africa: Some Critical Reflections" (2014) 8:1 Intl J of Transitional Justice 90 at 100-101 [Okafor \& Ngwaba, "The International Criminal Court"]; and Obiora Chinedu Okafor \& Uchechukwu Ngwaba, "Between Tunnel Vision and a Sliding Scale: Power, Normativity and Justice in the Praxis of the International Criminal Court" (2015) Africa Development 55 [Okafor \& Ngwaba, "Between Tunnel Vision"].

33 See Obiora Okafor, "Immunity for Sitting Heads of State under Article 46A bis of the Draft Protocol on Amendments to the Protocol to the Statute of the African Court of Justice and Human Rights: Some Heretical Thoughts" in Kujenga Amani, African Peacebuilding Program of the Social Sciences Research Council, New York (blog), online: $<$ http://forums.ssrc.org/kujenga-amani/2014/10/21/article-46a-bis-implications-for-peace-justice-and-reconciliation-inafrica/\#Obiora Okafor> [Okafor, "Article 46A bis"]; and Okafor \& Ngwaba, "Between Tunnel Vision", ibid. 
perspective). ${ }^{35}$ However, it is important to note that these positions can be assumed by one and the same person. For instance, a TWAILer may one day sit on a UN human rights body or the board of a human rights group, and return the next day to her "regular" job as a professor. Or she may spend some part of one day doing on-the-ground activist work and the rest of that day reflecting and writing on a Baxian theory. Or she may intersperse both kinds of work throughout her day. While one job may be different from the other, they do not necessarily exist in impermeable silos. What is more, to be as effective as s/he can be in enacting a form of TWAIL praxis in a non-academic setting, the situated TWAIL participant must plug into the TWAIL electricity grid that is kept alive largely by TWAILers who have mostly remained external observers.

\section{The Recognition of the Growing Need to Reach Beyond the Typical Sites of Engagement Toward the Non-typical:}

Here, I am beholden to the work of Luis Eslava and Sundya Pahuja who have asked and answered the question: apart from the "typical international legal places," to what kinds of sites, places, material, people, institutions, customs, practices, norms, and so on, must we pay attention? As they have put it, TWAIL praxis (what might be referred to as either execution-in-contemplation or contemplation-in-execution) needs to pay more attention to:

...the practices that occur, not only through typical international legal places, but also through many other sites and objects in which international law operates today. In particular, it is crucial that we start examining the way[s] in which international law unfolds on the mundane and quotidian plane through sites and objects which appear unrelated to the international. Administrative procedures, subject formations, spaces and artifacts that are usually identified as expressions of other normative orders, social spheres or simply innocuous technical or commercial things, are the very material sites in which international disciplines are at work. ${ }^{36}$

I must confess that my own non-academic praxis (hopefully transmitted on a TWAIL frequency) has focused less on the non-typical international legal places that Eslva and Pahuja refer to, and more on the typical ones. As such, I must also warn that the reflections offered in this paper on my own attempts to enact a type of TWAIL praxis are biased somewhat in the direction of the latter.

35 Ibid at 465-471. See also M McDougal and H Laswell, "Criteria for a Theory about Law" (1971) 44 S Cal L Rev 362 , at 364.

36 Eslava \& Pahuja, supra note 24 at 109. 


\section{The Better and More Exact Appreciation of the Opportunities and Limitations of (International) Law and Lawyers while Engaged in Praxis within Non-academic Habitats:}

As well-appreciated as this insight is, ${ }^{37}$ especially among schools of critical scholarship such as TWAIL, Martti Koskenniemi's reflections on it remind us that - at the very least - the specificities of the ways in which this truism operates within international institutions and in relation to the work of on-the-ground groups require constant reappreciation. As Koskenniemi has put it, his experience for a time as the legal adviser of the Finnish delegation on the UN Security Council made it clear to him that international law and lawyers generally play a more marginal role in the dramas that are enacted in the atmosphere of high politics that characterizes such non-academic habitats. ${ }^{38}$ As he recalled, "where the political framework was stable, the lawyer was the...[hand servant] of the politician, helping out if new language for negotiation and consensus was needed" but "things looked different when a non-routine issue emerged". In such circumstances, international law and lawyers assumed a more central role. ${ }^{39}$

\section{A Commitment to a Broadly Integrated and Interdisciplinary Style/Substance:}

This point flows logically from an appreciation of the discussion in the last subsection, and is already well-recognized by TWAILers. If politics (or at least non-legal maneuvers and the like) more routinely plays the central role in the non-academic habitats in which we seek to enact TWAIL praxis, then our praxis must adjust to the context, and integrate (as much as is possible and desirable) both the legal and the political. What is more, as is well recognized, a law/politics binary is not even possible. For, as Koskenniemi has long observed in the context of his work at the UN Security Council, "political choices... [tended to be] posed the moment the legal debate started" and there were no "separate pigeon-holes" for "law" and "politics," as "law and politics seemed coherent and separate, yet related to one single entity." 40

\section{The Recognition that the Longer Term Goal of TWAIL Praxis is Transformative and not to Merely Effect Marginal Change:}

As this is a fairly obvious point about which TWAILers tend to agree, there is little more to say here.

Overall therefore, it is - more or less - with this kind of theoretical/conceptual framework in mind that I have (off and on) sought to enact a TWAIL praxis (in the non-academic sense), both within and in relation to specific international institutions and on-the-ground groups. In the next

37 For example, see Gerald N Rosenberg, The Hollow Hope: Can Courts Bring about Social Change? (Chicago: The University of Chicago Press, 1993).

38 See Koskenniemi, supra note 35 at 473.

39 Ibid at 473-474.

$40 \quad$ Ibid at 475. 
section of the paper, I analyze some of these experiences, before offering some reflections in the two sections that follow it on the promise and perils of such attempts at close engagement by TWAILian international (human rights) law scholars.

\section{A TWAILER TURNS TOWARD INTERNATIONAL HUMAN RIGHTS INSTITUTIONS AND ON-THE-GROUND GROUPS}

\section{A. On my Partial Embedment at the UN}

In 2011, I was nominated by Nigeria and the African geo-political group at the UN, and elected by the UN Human Rights Council, to membership in a relatively obscure UN body known as the UN Human Rights Council Advisory Committee [HRCAC]. ${ }^{41}$ The HRCAC is the principal subsidiary body of the Council and its "think tank". A year later, I was elected its Vice-Chairperson/Rapporteur. I was re-elected to this body in 2014. This body serves as the "think-tank" of the Human Rights Council and consists of eighteen human rights experts (mostly professors, but also a few judges, former diplomats, and practitioners). ${ }^{42}$ In seeking election to the HRCAC, I had a reasonably well-developed sense of purpose. I saw my possible election to, and service on, that body as an opportunity to, as much as possible, enact a form of TWAIL praxis in that non-academic environment and within the bowels of relative power. I was aware of and inspired by the ideational and other kinds of impact that some other critical internationalists who had gone before me had made in the predecessor body to the committee I was asking to be elected to, namely the defunct UN Sub-Commission on the Promotion and Protection of Human Rights. ${ }^{43}$ The widely disseminated and highly influential report written for that SubCommission by two of its former members, Joe Oloka-Onyango and Deepika Udagama, readily comes to mind. ${ }^{44}$

Nevertheless, I was also aware that the body that I was going to sit on was significantly weaker than its predecessor; and that it had been deliberately weakened for different reasons in each case by a previously unlikely grand coalition of Western and Third World states. For example, unlike its more powerful predecessor, the HRCAC cannot pass even a mere resolution. ${ }^{45}$ The HRCAC can only pass and make recommendations to the diplomats in the Human Rights Council who in turn ultimately report to politicians in their capitals. ${ }^{46}$ And, more importantly, while it can discuss any matter it wants to consider, the HRCAC cannot write a report on that matter, or make any recommendations in relation to

\footnotetext{
41 For more on this body, see the website for the UN Human Rights Council Advisory Committee, online: $<$ http://www.ohchr.org/EN/HRBodies/HRC/AdvisoryCommittee/Pages/HRCACIndex.aspx>.

42 Ibid.

43 See the website for the UN Sub-Commission on the Promotion and Protection of Human Rights, online: $<$ http://www2.ohchr.org/english/bodies/subcom/> .

44 See J Oloka-Onyango \& Deepika Udagama, "The Realization of Economic, Social and Cultural Rights: Globalization and its Impact on the Full Enjoyment of Rights", UN Doc E/CN.4/Sub.2/2000/13 (15 June 2000), online:

$<$ http://www1.umn.edu/humanrts/demo/Globalization_Oloka-Onyango,Udagama.pdf $>$.

45 See Institution-building of the United Nations Human Rights Council, UNHRCOR, $9^{\text {th }}$ Meeting, UN Doc A/HRC/5/1 (2007) at paras 65-84.

46 Ibid.
} 
it to the Human Rights Council, unless and until it is so authorized by the Council. ${ }^{47}$ Against this background, I was and remain well aware of the fact that the opportunities for deploying my position on this body to make an appreciable TWAILian impact on international (human rights) law and praxis were significantly circumscribed and necessarily limited. Even more significantly, I was certainly not naïve as to the embedded and other limits of even the entire UN system (of which my own committee is only a small part), and of the formal texts we prepared and disseminated, in affecting the trajectory, orientation and substance of international (human rights) law and action, what's more the real politic of international relations. Such institutions and texts are, after all, almost always either relatively weak in the knees in the face of robust power, ${ }^{48}$ or "just words" which then require social mobilization and action to come alive! $!^{49}$

Yet, I was also as aware - or at least I imagined - that there are always worthwhile spaces and opportunities to occupy and utilize within such institutions; spaces that would sometimes allow one to have significant effect on the debates and recommendations of the HRCAC itself and more powerful organs within the UN (such as the Human Rights Council, the General Assembly and even the Security Council). I was also aware that if one is insightful, creative and effective enough, such spaces can be harnessed to yield even more significant dividends. After all, there were many states and other actors at the UN which, at the very least, on a case-by-case basis, seemed to care for and push in favour of the kinds of issues I cared for and wanted to work in favour of as a TWAILer. At the very least, I knew that my taking a seat as part of the African group on that body will have a valuable displacement effect on the large group of less-TWAIL minded professors, judges, and lawyers who tend to dominate the African international law scene. My taking a seat on the HRCAC meant one less such voice on that body. I also intended my membership on that body to have a kind of emplacement effect, in the sense that my presence on the HRCAC would - likely for the very first time - place TWAIL firmly within the inner sanctums of that living organism and its habitat, and allow our ideas and concerns to better penetrate that body and flow more fluidly in its veins. I saw myself as an agent for the infusion of as many TWAIL ideas as possible into the HRCAC, and through that body to the Human Rights Council, and beyond.

I soon came to realize that to be as effective as possible in achieving this goal I had to be clear enough from the outset as to what TWAIL praxis would require of me in this particular international institutional context, and in each scene of the many dramas that would continually unfold within it. I also had to ensure that my interventions were as technically competent and rigorous as possible (in order to keep the respect of my colleagues, many of whom are among the brightest in the international law world). In this particular "think tank" setting, the more rigorous and sound one's contributions are, the more one's colleagues will respect her, and the greater one's chance of successfully infusing any ideas (TWAIL or otherwise) into the body's deliberations and decisions. As importantly, I also realized that even the requisite technical international legal and policy-oriented competence were, on their own,

47 Ibid

48 See Obiora Chinedu Okafor, “Attainments, Eclipses and Disciplinary Renewal in International Human Rights Law: A Critical Overview" in David Armstrong, ed, Routledge Handbook of International Law (Abingdon, UK: Routledge, 2011) 303 at 310-314.

49 See Joel Bakan, Just Words: Constitutional Rights and Social Wrongs (Toronto: University of Toronto Press, 1997). 
hardly enough in this institutional and highly political environment. These were only the minimums one needed to possess to become effective. One also had to nimbly deploy diplomatic skills to get things done. And so my "mission strategy" had both a substantive and stylistic component to it, and, indeed, it had to.

To what extent has this mission strategy worked thus far, three-and-a-half years into my maximum six-year service on this particular UN body? To what degree have my goals for this iteration of my TWAIL praxis been realized? And are these goals even realizable at all? Am I just a naïve institutionalist and/or starry-eyed optimist? In the rest of this short sub-section, I will attempt to reflect briefly on this question in the context of the work that the HRCAC has done during my time on it. First, let me point out that although all members have to, in the end, participate in the work of the HRCAC on each and every one of the mandates from the Human Rights Council that are dealt with while s/he sits on that committee, a member tends to be more significantly involved in the discharge of the particular mandates in respect of which $\mathrm{s} / \mathrm{he}$ is a member of the sub-group of the HRCAC constituted to take primary charge of that file. These are referred to as drafting groups. I should also note that such involvement ratchets up considerably if that member is elected the rapporteur (i.e., chief researcher/writer) of the relevant drafting group.

Secondly, it is important to note at the outset that of the twelve mandates which the HRCAC has dealt with to a significant extent while I have held a seat on that body, ${ }^{50} \mathrm{I}$ have thus far served on the drafting groups that have primarily researched and prepared the reports of the HRCAC relating to seven of these mandates. ${ }^{51}$ Importantly, I served as the rapporteur of the drafting group on the practical ways and means of international cooperation in the field of human rights, drafted a significant portion of the report of the drafting group on human rights and unilateral coercive measures, and served as the chair of the drafting group on technical cooperation for the prevention of attacks against persons with albinism. Thus, I have so far had the greatest opportunity to shape the work and recommendations of the drafting group and the HRCAC in relation to the mandate on international cooperation, in respect of which I served as the rapporteur and prepared the draft report that was adopted eventually by the entire HRCAC

50 These are those on: human rights and international solidarity; enhancing international cooperation in the field of human rights; right to peace; promoting human rights and fundamental freedoms through a better understanding of the traditional values of human kind; human rights and issues related to terrorist hostage-taking; practical ways and means of enhancing international cooperation in the field of human rights; the negative impact of corruption on the enjoyment of all human rights; technical cooperation for the prevention of attacks against persons with albinism; human rights and unilateral coercive measures; local government and human rights; promoting human rights through sport and the Olympic ideal; and the protection of human rights in post-disaster/post-conflict situations. For detailed information on these mandates and the work/reports of the HRCAC on them, see the website for the UN Human Rights Council Advisory Committee, online: <http:/www.ohchr.org/EN/HRBodies/HRC/AdvisoryCommittee/ Pages/HRCACIndex.aspx>.

51 These are those concerning: international cooperation, right to peace, traditional values, terrorist hostage-taking, practical ways and means of international cooperation, the negative impact of corruption on the enjoyment of all human rights, albinism; and unilateral coercive measures. For detailed information on these mandates and the work/reports of the HRCAC on them, see the UN Human Rights Council Advisory Committee website, ibid. 
and forwarded to the Human Rights Council, where it was well received on the whole. ${ }^{52}$ I did, however, also have appreciable impact on the committee's work and recommendations in relation to some other mandates, especially the traditional values and unilateral coercive measures mandates.

With regard to the mandate of the HRCAC to prepare a study and offer research-based advice to the Human Rights Council on the practical ways and means of enhancing international cooperation in the field of human rights, I utilized the opportunity of my election as rapporteur of the drafting group of the HRCAC on this topic to ensure that the substance and tone of the report reflected as much as possible my TWAIL orientation. Among other things, I and like-minded colleagues worked hard to ensure that the report highlighted the problematic ways in which international human rights discourse tended to function as a monologue rather than a real dialogue, and the need for it to become much more of a twoway traffic than it has hitherto been. ${ }^{53}$ Along these lines, the report warned that "the constructive dialogue that drives and reflects meaningful international cooperation is far less likely to occur unless it is based on the idea that human rights knowledge ought to circulate in a multi-directional way among the World's peoples." ${ }^{54}$ This aspect of the report thus spoke to the fact that the marginalization of Third World voices has been a recurring decimal in TWAIL human rights work. Secondly, in line with an earlier report on the subject, the report also highlighted the negative impact on such international human rights cooperation of the selectivity that results from the "logic of power." ${ }^{.55}$ This is clearly a proTWAIL thing to do. Thirdly, while urging the Human Rights Council to make greater effort to deepen civil society involvement in its work, the report pushed at the same time for the de-marginalization of Third World social movements and NGOs and the de-centring of the Western NGOs who tend to dominate civil society space at the Council (including through the greater utilization of technology to bridge the physical and resource distance of these Third World groups from the Geneva location of the Council's deliberations). ${ }^{56}$ This was a clearly a pro-TWAIL move. Fourthly, the report advised the Human Rights Council to show strong support for the on-going push within sections of the UN to find ways of enhancing the effort to realize the right to development by holding development actors accountable while moving away as much as possible from the current "charitable giving" framework of international development. ${ }^{57}$ Again, this aspect of the report resonated with TWAIL, for, despite some concerns for the particular ways in which it has been deployed by some states, the enhancement of the right to development is of course a long-standing TWAIL concern. Fifthly, in discussing the ways and means of augmenting the resources available to be deployed toward the enhancement of international human rights cooperation, the report highlighted the agency and capacity that already exists in the Third World and the need to focus more on, utilize much more, and support far more robustly, such existing agency and capacity (for example through enhanced South-South cooperation). In particular the report highlighted the example of Nigeria's decades-old, but largely unacknowledged and unsung, Technical

52 See The drafting group of the Advisory Committee on the right to food, Preliminary Study of the Human Rights Council Advisory Committee on the Enhancement of International Cooperation in the Field of Human Rights, HRCACOR, $6^{\text {th }}$ Sess, UN Doc A/HRC/AC/12/CRP.2 (June 2014).

53 Ibid at paras 5, 20-21.

54 Ibid.

55 Ibid.

56 Ibid at paras 6-8.

57 Ibid at paras 10-13. 
Aids Corps Scheme through which that country shares its massive human capital with other Third World countries and peoples. ${ }^{58}$ It was, in part, in these kinds of ways that the report provided technical legal and other justification, further voice, and a measure of legitimization to the concerns already expressed by many delegations in the Council (an added resource in their hands). ${ }^{59}$ In this way did it also contribute to the process of the ongoing congealing of some of the positions that are pushed in it. The adoption of the report by a strong majority in the Human Rights Council is indicative of the strength and value of this ideational/practical contribution. All of these pro-TWAIL moves would not have, of course, been possible without the strong support of my colleagues on the HRCAC (including those that may not necessarily view themselves as TWAILers) who were persuaded to unanimously adopt the report - albeit with minor modifications.

Similarly, the mandate conferred by the Human Rights Council on the HRCAC to conduct research, and advise it, on promoting human rights and fundamental freedoms through a better understanding of the traditional values of humankind provided a great opportunity to infuse TWAIL into the discourse and decisions of both the HRCAC and the Council itself, or to at least heighten the circulation and role of TWAIL ideas and strategies within those bodies. ${ }^{60}$ It thus provided a great opportunity to enact a TWAIL praxis within this international institutional habitat. While I did not serve as the rapporteur of this report, I was a very active member of the drafting group that prepared the final draft document that was adopted by both the HRCAC and the Council. I had to play this kind of active role, for the topic at issue here implicated most fundamentally and directly the work that many TWAILers, including myself, had done over the years on the pitfalls of the constitutive orthodoxies that tended to govern international human rights praxis. ${ }^{61}$ For instance, as far back as 2001, my co-author and I had argued that the living international human rights praxis had been rendered highly problematic by its tendency to adhere to: (i) a heaven/hell binary (that clearly divides the World into a good West which invented a good normative framework called human rights and where little if any human rights violations occur, and a clearly bad Third World which historically lacked any ideas of human rights, which is riddled with human rights abuses, and which must then be saved by Western agents); (ii) a one-way traffic paradigm (implied by the flow of human rights knowledge in the heaven/hell binary scheme); and (iii) an abolitionist paradigm (that sees and treats Third World cultures or traditional values nearly always in monolithic, and fixed retrograde ways, and too often does so without knowing nearly enough about these cultures and traditional value systems). Against significant resistance from some members of the committee, a group

58 Ibid at paras 14-19.

59 See Koskenniemi, supra note 35 at 478 (arguing that "law's contribution...is not in the substantive responses it gives but in the process of justification that it imports into international policy and its assumption of responsibility for the policies chosen").

60 See Study of the Human Rights Council Advisory Committee on Promoting Human Rights and Fundamental Freedoms through a Better Understanding of the Traditional Values of Humankind, HRCACOR, 22 ${ }^{\text {nd }}$ Sess, UN Doc A/HRC/22/71 (December 2012) [HRCAC, Traditional Values of Humankind].

61 See Baxi, supra note 10; Makau Mutua, "The Politics of Human Rights: Beyond the Abolitionist Paradigm in Africa" (1996) 17 Mich J Intl L 591; Celestine I Nyamu, "How Should Human Rights and Development Respond to Cultural Legitimization of Gender Hierarchy in Developing Countries?" (2000) 41:2 Harv Intl L J 381; and Obiora Chinedu Okafor \& Shedrack C Agbakwa, "Re-Imagining International Human Rights Education in our Time: Beyond Three Constitutive Orthodoxies" (2001) 14 Leiden J Intl L 563. 
of us rallied relentlessly to ensure that, while culture was not deployed as a fixed and unchanging idea that absolved states and other actors from treating sections of their society more humanely, it was not treated in the abolitionist way urged by opposing members of the committee. I had to make repeated speeches and interventions that almost read like TWAIL seminar presentations. And we succeeded to a significant extent in the end. The report clearly affirmed in its substance and tone that culture could have both positive and negative impacts on human rights, depending on its nature and the context. ${ }^{62}$ In the context of the enactment of TWAIL praxis within such non-academic habitats, this was a teachable moment if ever there was one.

As importantly, the mandate conferred on the HRCAC by the Human Rights Council to provide it with a research-based report and advise on the negative impact of unilateral coercive measures [UCMs] on the enjoyment of human rights and on mechanisms to assess such impact and promote accountability, provided another great opportunity to, at the very least, heighten the circulation and role of TWAIL and similar ideas and strategies within both the HRCAC and the Council. ${ }^{63}$ While I was not the rapporteur of this report, I served on its drafting group and worked closely with the rapporteur of the report consulting with him frequently and in detail on all aspects of the report. I researched and provided him with a huge bibliography on the subject as well as a detailed summary of the contents of each bibliographic entry. In accordance with the agreed division of labor on the drafting group, I also wrote a key section of the draft report on technical international legal and policy justifications for choosing one kind or set of mechanisms for assessing the impact of UCMs over the other. ${ }^{64}$ And this portion of the report was adopted alongside other sections of the report by the drafting group, and later on by the entire HRCAC. ${ }^{65}$ I pre-presented this section of the report at a seminar on the same topic that was organized by the Office of the High Commissioner for Human Rights [OHCHR]. ${ }^{66}$ In both cases, I made a strong technical international legal and policy argument for the appointment of a special rapporteur on the too often negative impact of UCMs on the enjoyment of human rights, something that disproportionately and much more profoundly affects the lives of the nationals of the weaker Third World states. Thus, the report, the section of it that I drafted, and my presentation at the OHCHR seminar, ${ }^{67}$ provided what were seen by many as strong justification for the HRCAC and the Human Rights Council to act in the ways

62 For example, see HRCAC, Traditional Values of Humankind, supra note 61 at paras 32-72.

63 For example, see Report of the Advisory Committee on its thirteenth session, HRCOR, $13^{\text {th }}$ sess, UN Doc $\mathrm{A} / \mathrm{HRC} / \mathrm{AC} / 13 / 2$ (August 2014) at 6.

64 See Part IV, paras 43-58 of the Research-based Progress Report of the Advisory Committee containing Recommendations on Mechanisms to Assess the Negative Impact of Unilateral Coercive Measures on the Enjoyment of Human Rights and to Promote Accountability, HRCOR, $28^{\text {th }}$ sess, UN Doc A/HRC/28/74 (February 2015) (on file with the author).

65 See Report of the Advisory Committee on its thirteenth session, supra note 64 at 6.

66 See Obiora Chinedu Okafor, "Reflections on the Choice of Mechanism(s) for Assessing and/or Mitigating the Adverse Effects of Unilateral Coercive Measures on the Enjoyment of Human Rights" (Paper delivered at the Workshop on the adverse effects of unilateral coercive measures of the enjoyment of human rights, held at the United Nations Office in Geneva, 23 May 2014) [Okafor, "Reflections"].

67 See The Office of the United Nations High Commissioner for Human Rights, Proceedings of the workshop on the impact of the application of unilateral coercive measures on the enjoyment of human rights by the affected populations, in particular their socioeconomic impact on women and children, in the States targeted, HRCOR, $27^{\text {th }}$ sess, UN Doc $\mathrm{A} / \mathrm{HRC} / 27 /($ July 2014) at paras 17-22. 
they eventually did. The HRCAC adopted the report with relatively minor modification. ${ }^{68}$ For its own part, the Human Rights Council took the remarkable step of not waiting for the report itself to be submitted before acting on the HRCAC's eventual recommendation that it appoint a special rapporteur on UCMs. The Council acted simply on the strength of the report of the proceedings of the OHCHR seminar. One can only surmise from these facts that the paper I presented at that seminar, calling for precisely this step to be taken, played some justificatory role in the reaching of this decision. Lastly, regarding the HRCAC's report itself, my colleagues and I have been successful in making sure that it strongly recognizes the ways in which UCMs can and do undermine, at times quite profoundly, the basic human rights of targeted peoples, who are almost always Third World peoples. To be clear, the reason I worked very hard to persuade my colleagues and the Human Rights Council that a special rapporteur on UCMs should be appointed was not because I felt that this act would somehow solve the problem of the negative impact of UCMs on the enjoyment of human rights in Third World countries. Rather, I worked hard toward this goal in order to expand the repertoire of resources available in the hands of a "coalition of the willing" (states, activists, HRCAC members, etc.) to struggle against this ill. A special rapporteur is simply a resource and not a panacea.

On the whole, regarding this TWAILer's (admittedly partial) embedment within this one UN body with the goal of enacting a TWAIL praxis within that environment - it is fair to conclude that while no earth-shaking attainments have been realized, or could even have been reached, as a result of this particular set of maneuvers, some modest but significant impact has nevertheless been made as a result, albeit within the narrow confines of the work of the HRCAC and the Human Rights Council. The ideational and practical orientation of those bodies has been affected to some extent by my sustained attempts, in alliance with willing colleagues, to enact as effectively as is possible a form of TWAIL praxis. As the ways of the UN are generally as slow as the tortoise crawls, it is as yet too early to fully assess the impact of this attempt to enact a TWAIL praxis. Yet, I am convinced that the HRCAC and the Council have profited in significant, if modest measure, from the enhanced circulation of TWAIL ideas/justifications that I and others on the HRCAC have sometimes authored. I am also convinced that even these modest successes would not have been possible, or would not have been as appreciable, without the deployed cocktail of rigorous technical international legal and policy argument, diplomatic maneuvers, and TWAILian knowledge/clarity/commitment that my like-minded colleagues and I brought to bear on our work within the HRCAC. It was also helpful that I was able to move as nearseamlessly and contemporaneously as I did between my job as a scholar/teacher and my more implementation-oriented and more practitioner-like role on the HRCAC.

\section{B. On my Sporadic Engagement with on-the-Ground Groups}

At the outset, I must note that close engagement with the on-the-ground activist groups (i.e., social movements, NGOs and the like) which, in their engagement in "the politics of the multitude," strive as best they can to struggle for human rights around the world, ${ }^{69}$ has for me been largely sporadic, rather

68 See Report of the Advisory Committee on its thirteenth session, supra note 64 at 6.

69 See Balakrishnan Rajagopal, "Counter-Hegemonic International Law: Re-Thinking Human Rights and Development as a Third World Strategy” (2006) 27:5 Third World Q 767 at 780 (following Hardt and Negri) [Rajagopal, "CounterHegemonic"]. 
than anything close to quotidian. While I have studied these groups closely enough for decades and written many books and journal articles on their work, I have - aside from once being a card-carrying member of one of these groups - rarely been as embedded with them as I would like. One can of course reflect on the many reasons why this has been so, but such a discussion is well beyond the scope of this paper.

Nevertheless, I have closely engaged with these groups in other significant ways. The discussion that follows describes and reflects one such instance in which I have had a relatively fleeting, yet intense, engagement with some of these on-the-ground groups. In July 2014, I participated over a number of days at a meeting organized in Dakar, Senegal, by the Council for the Development of Social Science in Africa [CODESRIA] and the Africa Program of the Social Science Research Council of the USA $[\mathrm{SSRC}] .{ }^{70}$ The meeting was attended by a large cohort of key NGO and social movement figures from around the African continent, the representatives of a few foreign, or so-called international, NGOs, some representatives of NGO-funding agencies, CODESRIA and SSRC staff, and a number of African academics/intellectuals. ${ }^{71}$ The overarching topic of the meeting was the fraught yet important relationship between African states and African international institutions (on the one hand) and the ICC (on the other hand). ${ }^{72}$

The background to this discussion was that: every single one of the cases that have so far come up for trial before the ICC, or for which actual investigations (as opposed to mere preliminary examinations) were being conducted, is of African provenance; ${ }^{73}$ the ICC had made bold to indict a sitting African head of state (namely President Omar El Bashir of the Sudan) and had subsequently indicted a number of senior Kenyan leaders, two of whom were later elected and sworn in as president and vice-president of the country $;{ }^{74}$ and the African Union had engaged the ICC in a running battle over its indictment of these African leaders and its near-exclusive focus on Africans. ${ }^{75}$ An intense controversy had thus erupted over the ICC's work and approach, one that threatened to mar its on-going development as a new international judicial institution, and denude its legitimacy to a degree in certain parts of the world. $^{76}$

Going into this meeting, I was well aware of the ideological, normative, practical, and other factors that have shaped this controversy and conversation. For example, I kept in mind the fact that the behaviour of many African on-the-ground groups, including many of those who sent representatives to the meeting have been historically constrained in significant measure by the policy directions and attitudes of their mostly Western funders. ${ }^{77}$ This is not, of course, to argue that that these NGOs lack

70 See the website for the SSRC-CODESRIA Conference on "International Criminal Justice, Reconciliation, and Peace in Africa: the ICC and Beyond", online: <http://www.ssrc.org/event/ssrc\% E2\%80\%93codesria-conference-on$\% \mathrm{E} 2 \% 80 \% 9$ Cinternational-criminal-justice-reconciliation-and-peace-in-africa-the-icc-and-beyond $\% \mathrm{E} 2 \% 80 \% 9 \mathrm{D} />$.

71 Ibid.

72 Ibid.

73 Okafor \& Ngwaba, "Between Tunnel Vision”, supra note 33 at 9-11.

74 Ibid.

75 Ibid at 14.

76 Ibid at $12-13$.

77 See Obiora Chinedu Okafor, Legitimizing Human Rights NGOs: Lessons from Nigeria (Trenton, NJ: Africa World Press, 2006) at 123-150. 
agency, ${ }^{78}$ but simply to point out one of the important constraints they confront and navigate, one that exacts significant limits on the extent they can go in expressing one view or another. This is simply the hard reality of NGO politics in the poorer Third World areas of the world. ${ }^{79}$ I was also well aware of, and as disturbed as anyone else by the well-recognized reality of a significant measure of official impunity for gross human rights violations in many parts of the African continent. In this same vein, I recognized the imperative of struggling in whatever ways are possible and ethical in favour of the subalterns who suffer as a result. And lastly, I was as deeply aware that it was more or less the relative weakness of African states vis-à-vis most others in the world, and the vagaries of high international and domestic politics (and not the mere incidence of impunity), that propelled the ICC into its current geostationary orbit over only Africa. ${ }^{80}$

Predictably, and perhaps understandably, almost every single NGO representative at the meeting toed a strong pro-ICC line and rallied against the attacks on the ICC's approach that have been launched by a large number of African states and the African Union. They tended to emphasize the fact of the existence of significant official impunity and subaltern suffering on the continent, and hailed the ICC for its role in attempting to put an end to both of these phenomena. They also tended to point out - quite correctly - that many of the cases at the ICC were self-referred to the ICC by African states themselves. And they demanded to know why the African Union and almost all of these African states did not speak out against the ICC while that court was busy indicting lower level Africans (especially the domestic political opponents of these African leaders) until one of their own - a sitting head of state - was indicted. While this was a legitimate question to raise, it should be emphasized, though, that not every NGO representative at the meeting toed each and every one of these lines. There were some notable exceptions. The point here is that the vast majority of them did so.

Opinion was more divided among the academics present. While some agreed with the overall thrust of the arguments proffered and positions taken by the NGO representatives, others disagreed with it (even while agreeing with many of their factual statements and subsidiary arguments). Indeed, even the two avowed TWAILers at the meeting did not always agree with each other. Those that disagreed somewhat with the overarching NGO position that too often idolized the ICC, pointed out the need to complicate the analysis a bit more and assign fault to the ICC for an overall approach to its work that led it to focus rather excessively, and in a jarring and problematic way, on only prosecuting alleged perpetrators of international crimes from the African continent to the exclusion of all others.

In the paper I submitted and presented, in my contributions from the floor, and in the comments I made to delegates in the corridors of the meeting venue, I struggled to proffer and circulate alternative ideas and arguments that challenged the overly adulatory mainstream view of the ICC's relationships with African states. ${ }^{81}$ This, I did, even though I did not completely disagree with many of the points made by those who took this position. For example, between the ICC's position that it was merely

78 For example, the late Gani Fawehinmi, Nigeria's most successful and decorated human rights lawyer/activist operated outside, and was quite critical, of the over-determination of Nigerian human rights NGO approaches and focus by foreign-funders. See Obiora Chinedu Okafor, "Immanent Dualities? A Socio-Legal Analysis of the Character, Attainments and Limitations of Gani Fawehinmi’s Human Rights Praxis" (Abuja: NIALS Press, 2012).

79 See Baxi, Future of Human Rights, supra note 10.

80 See Okafor \& Ngwaba, "The International Criminal Court," supra note 33 at 15-16.

81 See Okafor \& Ngwaba, "Between Tunnel Vision”, supra note 33. 
following the evidence in filling its docket with only African cases and the African Union's view calling for the indictment issued against President Bashir of the Sudan to be either deferred or withdrawn, and railing against the ICC's near-exclusive focus on Africa, ${ }^{82}$ I suggested to my NGO and academic colleagues that rather than ask for "less" prosecutions, perhaps we should ask for "more" (i.e., the prosecution of more perpetrators, only this time from other continents). Similarly, in response to the suggestion by some of those who held the mainstream view that the wrong persons (African leaders) were calling for ICC reform, I suggested that the right people (on-the-ground activists) were not critically examining the ICC either or making the obvious points in public about the potentially delegitimizing properties of the ICC's tunnel vision and behaviour toward Africa. Perhaps, if they had been making these points, the wrong people would not have had to make them. For, perhaps, the ICC might have been better guided at an earlier stage in its approach to its work. Concomitantly, I also argued that, guided by the right people - the NGOs who would be seen as more friendly at the ICC that court (especially its first prosecutor) might have been able to take the argument of excessive selectivity away from the mouths of some African leaders by including in the ranks of those it was prosecuting even two or three other perpetrators from other parts of the world. This would not have been all that difficult given the high incidence of violations of international crimes under the ICC's jurisdiction by persons from other continents as well. ${ }^{83}$ While the ICC cannot simply prosecute whomsoever it wants (for jurisdictional and other rules must first be satisfied),${ }^{84}$ the fact that it is now conducting preliminary examinations into events that occurred years ago in a large number of nonAfrican states suggests that it could and should have commenced prosecutions in these other places long before now. ${ }^{85}$

On the related but still discrete issue of the clause inserted into the new Protocol amending the Protocol on the proposed African Court of Justice and Human/Peoples' Rights granting transactional immunity while in office to sitting African heads of state from prosecution at the international criminal law chamber to be established within that court, I also proffered and disseminated an alternative, TWAIL-driven perspective that differed from the mainstream position taken by most of the NGO representatives in attendance. As my position on this specific issue has been articulated and published in the USA Social Science Research Council African Program's blog, Kujenga Amani, suffice it to substantially reproduce a portion of it here. ${ }^{86}$ In my contribution to the discussions in Dakar, and in the Kujenga Amani piece, I tried to educate the representatives of these on-the-ground groups about the alternative, more TWAILian, ways of imagining the question; albeit in as practical a manner as I could. I argued, inter alia, that regarding the relevant provision of that treaty, Article 46A bis, I did have some heretical, yet more practical and more realistic thoughts than most of them had. These were that without

82 See Manisuli Ssenyonjo, "The Rise of African Opposition to the International Criminal Court's Investigations and Prosecutions of African Leaders" (2013) 13 Intl Crim Law Rev 385.

83 See Okafor \& Ngwaba, "The International Criminal Court," supra note 33.

84 See Articles 12-17 of the Rome Statute of the International Criminal Court, 17 July 1998, 2187 UNTS 90 (entered into force 1 July 2002), online: <http://www.icc-cpi.int/en_menus/icc/legal\%20texts\%20and $\% 20$ tools/official\%20journal/Pages/rome\%20statute.aspx $>$.

85 For a list of the preliminary examinations being conducted by the ICC, see the website for the International Criminal Court, online: $<$ http://www.icc-cpi.int/en_menus/icc/Pages/default.aspx $>$.

86 See Okafor, "Article 46A bis," supra note 34. 
necessarily being in favour of the grant of immunity to sitting heads of state under the treaty at issue, thoughtful observers of this development must nevertheless account for and respond to the somewhat paradoxical ways in which adherence to the opposing, supposedly pro-human rights, approach (i.e. not granting this kind of immunity) may in fact hinder the attainment of their own end-goal of protecting more and more ordinary Africans from repression and violence. I suggested that, somewhat paradoxically, the seemingly pro-human rights approach of targeting sitting heads of state for prosecution before international courts can - in certain contexts - lead to the exacerbation of domestic repression, conflict and/or violence. Here, the point I made to them was that - at least in the context of many African states - when many a sitting head of state are in real danger of being hauled, tried and convicted before an international criminal court, given the better protection that sitting tight in office usually affords most of them, the incentive structure that would be put in place would be one that would tend to encourage all-too-many highly repressive and violent leaders to do all that is possible to remain in office as long as they possibly can, so as to reduce the likelihood of their being ousted from office by opposing internal forces, something that would be more likely to lead to their arrest and prosecution at the relevant international criminal court. This is especially so when the relevant leaders are not favoured by the global power matrices/calculus of the day. And not surprisingly, the road to the continued stay in office of such leaders tends to be lined with the bodies of killed, tortured or otherwise seriously abused opponents and ordinary citizens. Thus, in the real life world, the grant of immunity to sitting heads of state (something that is temporary and transactional) may not necessarily function in an anti-human rights a manner as many have loudly suspected. To the contrary, it could actually work better to protect more ordinary Africans from augmented repression and violence than the targeting of such sitting leaders for international prosecution could ever hope to achieve. It could also lead to more (not less) prosecutions before the international criminal courts; albeit of lesser officials than the head of state (e.g., ministers and Army chiefs). What is more, the temporary immunization of sitting heads of state from prosecution could in fact suitably dull their minds in the meantime to the real dangers that many of them may face when they leave office. Just ask Hissen Habre. ${ }^{87}$ Crucial to the calculus here is that these leaders can do significantly less harm to the human rights of ordinary people in their respective countries if they are targeted for international prosecution while out of office.

Overall, what I tried to do in Dakar was to, as best I could, enact a kind of TWAIL praxis, a praxis that could project TWAILian goals in the complex, somewhat unreceptive circumstances in which I found myself. To be as effective as they possibly could, my TWAIL-driven arguments still had to be technically sound, policy-oriented, implementation-focused, politically-aware, and sensitive to the context of my main audience (mostly committed on-the-ground activists who were locked in firm embrace with the ICC). In my view, these arguments resonated among a small number of the more reflexive NGO representatives (though only to a modest degree). For example, the closing keynote delivered by a senior NGO activist and Chair of the National Human Rights Commission of Nigeria, Dr. Chidi Odinkalu (one of the most cerebral activists on the continent), incorporated some of these ideas. For me this was again a teachable moment, as I helped to offer these on-the-ground activists alternative

87 The Associated Press, "Trial on War Crimes Is Set for Ex-President of Chad", The New York Times (14 February 2015), online: <http:/www.nytimes.com/2015/02/15/world/africa/trial-on-war-crimes-is-set-for-ex-president-ofchad.html?_r=0 $\geq$. 
TWAIL-driven ideas, visions and strategic maneuvers which were not already visibly on their plates, or were not already as boldly outlined. To have been able to do so, in as optimal a way as possible, I had to reach into my understanding of TWAIL theories and methodologies. But I also had to be pragmatic and realistic in offering these activists some ideas on which they can actually act (within their ideological and other boundaries), without rejecting completely an international judicial institution and an end goal of ending impunity for international crimes that they were very strongly committed to. I had to, and did, offer them some ideas that would allow them to critique and oppose important aspects of the ICC's behaviour while remaining faithful to their normative and institutional commitments to that body. Merely railing openly against global imperialism in the human rights field was not for these groups a real option. I also had to and did offer them some arguments that could allow them to support the new African Court of Justice and its state immunity regime while remaining faithful to their end goal of protecting more and more Africans from violations and abuse.

\section{THE PROMISE OF CLOSE ENGAGEMENT WITH INTERNATIONAL INSTITUTIONS OR “ON-THE-GROUND” GROUPS}

\section{A. The Strategic/Tactical Promise ${ }^{88}$}

A very important strategic/tactical promise of our close engagement with international institutions and on-the-ground groups is that it will allow us a significantly better chance of bridging - as best we can - the "two worlds" 89 in which TWAILers (on the one hand) and diplomats, international/domestic civil servants, politicians, and activists (on the other hand), tend to inhabit. This divide appears to be mostly physical, but it is also a mental one, at least in the sense that very few of even those diplomats, international civil servants, activists, etc, who are in my experience anxious for, or would benefit from, TWAIL insights appear to even know about TWAIL's existence, what more its ideas. ${ }^{90}$ Bridging the divides that separate us from these actors will allow TWAIL ideas to flow more easily and robustly into the deepest recesses of the bodies and groups that we must influence much more in order to optimize our capacity to help effect the kinds of global/local social change we desire. If this kind of optimization is to be realized, TWAIL thinking and action needs to unite more fully with diplomatic/official/activist action and thought. Nothing less than a partial bridging of habitats and mentalities is called for here.

Secondly, just as a partial embrace of diplomats/officials/activists (i.e., of praxis beyond the academe) will help TWAIL to more rapidly and robustly drive toward its end goals, our own intellectual

88 The phrase "strategic/tactical" is used in this paper so as to indicate the fact that some of the promises and perils discussed under that rubric are strategic (in the "long term" and/or the "structural" senses in which this term is used by Robert Knox), or tactical (in the sense in which the same author uses them), or both. As such, a detailed discussion of the distinctions between those two terms and the ways in which they have been used or abused in the scholarly literature is not warranted here. See Robert Knox, "Strategy and Tactics" (2010) 21 Finnish YB of Intl L 193.

89 This idea is adapted from Lucie White's work on the two worlds in which women's lawyers and economic development bureaucrats appear to live in the Ghanaian context. See Lucy White, "Two Worlds of Ghanaian Cause Lawyers" in Austin Sarat \& Stuart Scheingold, eds, Cause Lawyering and the State in a Global Era (Oxford: Oxford University Press, 2001) 35 at 64.

90 See Saeid Mirzaei, "Chair's Opening Remarks" (Delivered at the Annual CCIL Conference Panel on Third World Approaches to International Law, Ottawa, Canada, November 2013). 
skills and approaches will in the result enrich and help improve the very institutional and on-the-ground praxis that we would have engaged. This point is so well acknowledged in the literature that it need not detain us here. Suffice it to state that intellectuals like us achieve this kind of enhancement effect by filling knowledge gaps within the relevant institutions or groups, providing a more reflexive approach to their work, helping frame and name abuses, re-shaping existing movements, and even spurring new ones. ${ }^{91}$ The strategic/tactical "value-added" that international lawyers (including scholars like us) have brought and can bring to the on the ground work of NGOs and social movements in the human rights field is also well documented. ${ }^{92}$

Thirdly, becoming more embedded or engaging more closely with these diplomats/officials/activists will afford the international (human rights) law scholar a greater chance of being able to generate, recognize and seize the kind of teachable moments which can exert ideational and other influence on institutions and groups which often wield great political, social and economic power in our world, and which tend to author or change policy/practice. Clearly, the ability to exert such influence will help improve our chances of more rapidly and robustly driving toward TWAIL's goals. What could be more effective in this regard than us engaging as frequently as we can in "pedagogies of the oppressed"93 within the very bowels of institutional or activist power, and having the very high officials/diplomats/civil servants/activists who control these bodies or groups learn to some extent from TWAILers or our work?

Fourthly, there is a sense in which enacting a form of TWAIL praxis beyond the academe by participating closely in the work of international institutions and on-the-ground groups can result in our helping give birth to aspects of international human rights itself. As Baxi teaches us, "human rights values, standards, and norms are created by people's praxes of resistance and struggle." "In the same vein, he has also correctly noted that "the real birthplaces of human rights are far removed from the ornate norms of diplomatic conferences and are found, rather, in the actual sites (acts and feats) of resistance and struggle." 95 Baxi's point here is not as much to exclude and de-value the "birthing" of human rights texts that occurs in international institutions (bodies which remain as state-centric as ever), as it is to make clear that the praxis of the on-the-ground groups also matter as much (or even much more) in the relevant norm-generating processes. And so, close engagement with social movements and the work of international institutions (such as the Human Rights Council and the HRCAC), literally allows international (human rights) law intellectuals like us to participate more actively in the creation or refinement of international human rights values, standards, norms, processes, etc. The main benefit to us here is the much greater chance of exerting our influence on the DNA and character of the human rights offspring of these processes. Deep participation in such a politics can matter, and matter quite

91 For example, see Stephen Friedman, "From Classroom to Class Struggle: Radical Academics and the Rebirth of Trade Unionsim in the 1970s" (2014) 49 J of Asian \& African Studies 526; and Rachel Schurman \& William Munro, "Ideas, Thinkers, and Social Networks: The Process of Grievance Construction in the Anti-Genetic Engineering Movement" (2006) 35 Theory Society 1.

92 For example, see Obiora Chinedu Okafor, The African Human Rights System, Activist Forces and International Institutions (Cambridge: Cambridge University Press, 2007).

93 See Paulo Friere, Pedagogy of the Oppressed (New York: Continuum, 2007).

94 See Baxi, Future of Human Rights, supra note 10 at 94.

95 Ibid. 
significantly. For if law (the very law which TWAIL focuses on and often accuses of responsibility for the suffering and disadvantage of all too many Third World subalterns) is in reality congealed or legitimized politics, then deep participation in the politics of the institutions and/or groups in which the processes of the congealing or legitimization of human rights politics into human rights law are enacted can matter (and this will be so both within and without the Habermasian "communicative action" framework) ${ }^{96}$ This kind of deep participation will not, of course, totally change the world overnight, but it does have some potential to help change it significantly in our own time.

Fifthly, in engaging even more closely in the relevant international institutional and activist environments, we have a greater chance of breathing life into our own critiques of international law and order, animating them into (non-academic) political action, and making them do the very jobs we want them to do for the Third World subaltern. Since ideas play an important role in driving both the domestic and international systems, ${ }^{97}$ we can in this way significantly enhance the chances of seeing our ideas markedly affect the praxis of the relevant on-the-ground groups and international institutions, and through them the "world out there". As TWAIL is an avowedly scholarly and political movement, this particular strategic/tactical promise of close engagement becomes even more important. However, it must be noted that as not all international institutions and on-the-ground groups are the same, some may be more effectively subjected to TWAIL praxis than others. This could be because of the structures of such institutions (e.g., the IMF and World Bank's voting arrangements and structures make them more resistant to Third World influence than say the UN Human Rights Council), or the varying nature of the relevant on-the-ground groups (e.g., elite human rights organizations such as Amnesty International and Human Rights Watch present different, and perhaps tougher challenges to TWAILers than Third World peasant movements).

Lastly, such close engagement and the outlined strategic/tactical benefits that it can generate also hold the promise of helping sustain the TWAIL movement into the future. For, as Kenneth Karst once warned, "a movement, even an intellectual movement, needs some sense of - well, movement. Otherwise it dissolves." 98 The achievement of such a sense of movement can, of course, result from reaching almost all of a movement's possible goals and not just from negative stasis. Yet, in both cases the lesson would be the same. In any case, as TWAIL is nowhere near the realization of its overarching goal of achieving a global order favourable to the Third World subaltern, it would do well to chew on Karst's insight.

96 See Burns Weston, "The Role of Law in Promoting Peace and Violence: A Matter of Definition, Social Values and Responsibility" in Michael W Reisman \& Burns Weston, eds, Toward World Order and Human Dignity (New York: Free Press, 1976) 114 at 117; and Thomas M Franck \& Mark M Munansangu, The New International Economic Order: International Law in the Making?, UNITAR Policy and Efficacy Studies No 6, 1982. See also J Habermas, Theory of Communicative Action, translated by Thomas McCarthy (Boston: Beacon Press, 1981) (making a more general point about the value of deep participation in social institutions).

97 See Ibironke T Odumosu, "Challenges for the (Present/) Future of Third World Approaches to International Law" (2008) 10 Intl Community L Rev 467 at 470.

98 See Kenneth L Karst, “Integration Success Story” (1996) 69:5 S Cal L Rev 1781, at 1792. 


\section{B. The Conceptual/Theoretical Promise}

In my own view, close TWAIL engagement with international institutions and on-the-ground groups holds at least four broad types of conceptual/theoretical promise for TWAILers. The first is that we will be enabled to see in bolder relief; the second is that we will gain or renew certain theoretical insights; the third is that it can position us to see how international law circulates and performs in non-typical sites which at first glance appear not to be related to the international; and the fourth is that it can help us do better at uncovering what Baxi and Parmar have referred to as "subjugated knowledges."

First, such close engagement will allow us to see in much bolder relief, in a kind of "high definition," the details and contours of the many dramas, politics, maneuvers, strategies, tactics, technologies, and so on, that go on or are deployed within the very non-academic habitats within which world order is largely constructed, re-jigged or affected in some way. This can lead to an increase not just in the quantity of observed phenomena but also in the quality of our appreciation of what we do observe. There is a real difference between looking at the backyard of a house from space and looking at it while sitting right there. Most of what a researcher with an electron microscope can readily observe and factor into her theories, her counterpart cannot usually observe or factor in. In the latter case, the world would more likely seem to be much freer from the blessings or plagues of micro-organisms than it would appear to be in the former situation. The latter researcher is not so much wrong as she is simply unable to observe. But her theory would nevertheless be relatively deficient. The former researcher is not so much right as she has just been enabled to observe. But her theory would still be relatively stronger than her counterpart's. Close engagement can therefore become the electron microscope or high definition lens with which we as TWAILers can become introduced to the tiny micro-dramas and nuances that together constitute the making and unmaking of international law and global order, and how they hang together to produce or unsettle certain processes or outcomes. As such, close TWAIL engagement holds the promise of allowing us to gain better or otherwise unavailable insights, and better explain our world. Our theory will become enhanced in the result (through the resulting processes of exemplification, complication, renewal, modification, or even partial or wholesale rejection). This point is not in the least contradicted by the fact that, as there is no radical separation between "object" and "subject," we are part of the terrain that we observe. Since there is no conflation as well between the two, there is still some zone in between, something to be regarded and examined.

Therefore, the second, related, conceptual/theoretical promise of such close engagement with international institutions and/or on-the-ground groups is the probable harvest of new or even better insights that can, as a result, be gained for our own intellectual work. The examples below of such insights work together to illustrate this point:

i. As many TWAILers have noted, since international law and order has not mostly given up its work in favour of power, domination and imperialism, ${ }^{100}$ and domination from past empires does

99 See Upendra Baxi, Human Rights in a Posthuman World (Delhi: Oxford University Press, 2007) at 19; and Parmar, supra note 26 at 365.

100 See Antony Anghie, "The Evolution of International Law: Colonial and Postcolonial Realities" (2006) 27:5 Third World Q 739 at 751. 
not present itself in the same forms today, ${ }^{101}$ a crucial TWAIL task is to focus on and better map/understand the specific and exact ways through which global power, domination and imperialism are constituted, renewed and circulated today. ${ }^{102}$ This includes a focus on how TWAIL's goals can still be achieved even in these contexts. These critical tasks cannot be discharged effectively without more close engagement with the habitats in which these phenomena are largely produced and projected.

ii. Close TWAIL engagement can also lead one to realize that there need not be any radical or even significant separation between working in the academe and toiling in the trenches beyond the academic realm. For me, such close engagement has led to the realization that my work at the UN (as an expert member of the HRCAC) has in fact been a largely seamless extension of my academic praxis. There has not for me been any sharp break between the two realms. Like a beach at high and low tide, the two jobs I do are - for the most part - two forms of the same reality ${ }^{103}$ Both jobs involve research, writing, dissemination, and formal/informal pedagogy. As I see it, a large swathe of the jobs or tasks which we, as TWAILers, might want to perform within or in relation to international bodies and on-the-ground groups would involve some combination of these tasks. This is not always the case, of course, but that has been my own experience. For, when I put on my UN hat, I do not therefore simply transform into a mere technician in the workshop of power. And when I put on my academic hat, I do not simply re-transform into some kind of a purified thinker who reflects completely aside and apart from "the world out there."

iii. Another conceptual/theoretical insight that close TWAIL engagement with international institutions and on-the-ground groups has offered me is the realization that the "internal perspective" on these bodies/groups (à la Koskenniemi) is neither the only perspective that I have nor the only one that I should have. I also possess, and should definitely possess, an "external viewpoint" on these bodies. Both perspectives should and do work hand-in-hand for optimal insight to become possible. Neither a "strictly internal perspective" (i.e., a comprehension of the situatedness of the relevant diplomats/officials/activists as participants rather than observers in these bodies/groups) nor a "strictly external" one (i.e., attempting to comprehend these bodies and groups entirely from the outside), can suffice to lead TWAIL to its promised land! ${ }^{104}$ As such, as ethnography teaches us, it is of course possible to act as a participant/observer. In any case, this last posture better describes my experience engaging the UN from within. It is also an accurate description (though to a lesser extent) of my experience with engaging on-the-ground groups. Yet, it should be said that praxis beyond the academic

101 See Michael Fakhri, "Law as the Interplay of Ideas, Institutions and Interests: Using Polyani (and Foucault) to ask TWAIL Questions" (2008) 10 Intl Community L Rev 455, at 456-457.

102 See BS Chimni, "Manifesto", supra note 7 at 48; Odumosu, supra note 98 at 470; and Fakhri, ibid at 456-457.

103 See Koskenniemi, supra note 35.

104 Ibid at 465-471; and Jouannet, supra note 14 at 4-5. 
terrain allows us to take better account of the "internal perspective" on such bodies/groups without necessarily adopting such a perspective in a wholesale or non-reflexive way. ${ }^{105}$

iv. Being on the inside of, or engaging closely with, the relevant institutions/groups can also enhance our TWAIL theory (and action) by revealing the precise locations and characters of the pressure points on which we must press our fingers to have a greater chance of getting the relevant "machines" to work toward enacting the kinds of socio-legal change we desire. It can thus help reveal the identities and locations of the chinks in the armours of power, domination and imperialism, so to speak. For instance, Koskenniemi's reflections on his time as the legal adviser of the Finnish delegation to the UN Security Council has taught us that international lawyers tend to have a better chance of impacting the debate and decisions in such bodies when non-routine issues emerge, and that we are likely to exert far less influence when the political framework is already stable. ${ }^{106}$ The TWAIL agenda and program can benefit much from the teasing out and incorporation of these kinds of insights. Regarding Koskenniemi's present insight, this may, for instance, mean that TWAILers should target a good measure of their nonacademic praxis toward the bodies and groups with important norm-creation roles (such as the Human Rights Council, HRCAC, WTO Appellate Body, international courts, and even social movements and NGOs). It could also equip us better to engage other kinds of bodies more effectively.

v. A closely related point is that close engagement will also allow TWAILers to see, or see more clearly, the exact and precise nature of the various spaces that are available or unavailable for resistance. As Rajagopal has correctly noted, international (human rights) law has, at the very least, been as historically hegemonic as it has been emancipatory. ${ }^{107}$ This is a very important point. For example, we should not ignore the ways in which a Third World coalition - however shifting its character and modest its attainments - more or less wields significant power at the Human Rights Council and in the HRCAC. Thus, the "encadrement" of the diplomats who work in the relevant delegations to the Human Rights Council, and a similar process of socializing those who serve on the HRCAC, will be quite important if we seek to resist human rights texts and moves that are biased against Third World peoples, or disadvantage them in any other way. And in my experience many such diplomats are already quite sympathetic to TWAIL and are ripe for encadrement. There are many simple ways to do so. For example, more of them need to be invited and attracted to TWAIL conferences, and more of us need to engage with them and feed them TWAIL literature and ideas. For here is a relatively significant space within the bowels of international institutional power in which "the rampant dis-regard of the lived experiences of Third World peoples" that many TWAILers have written about, has a very good chance of not being replicated. ${ }^{108}$ Speaking personally, it was through close engagement (my

\footnotetext{
105 See Jouannet, ibid.

106 See Koskenniemi, supra note 35 at 471-474.

107 See Rajagopal, "Counter-Hegemonic", supra note 70 at 769-775.

108 See Parmar, supra note 26 at 368; and Rajagopal, International Law from Below, supra note 30.
} 
embedment within the HRCAC) that I came to realize just how much this particular institutional space is open to the enactment of a kind of TWAIL "spring."

vi. As importantly, engaging closely enough with the relevant institutions/groups can also afford TWAILers certain insights which can help refine, and therefore enhance, our theories and understandings of "essentialism" and its critiques. Essentialism is, without doubt, generally problematic as a conceptual and methodological approach to knowledge or to seeing the world. For example, as Baxi teaches us, "essentialist constructions of the universal 'human' fail to acknowledge cultural diversity" and "the hegemonic conceptions of human rights allow little or no play for radical plurality." 109 This understanding is almost canonical in TWAIL human rights scholarship! Yet, as many TWAILers realize, some critiques of essentialism have at times gone too far. For instance, as Baxi has queried, "what is there to subvert if identities are all fluid and the subject is no more?" 110 More particularly for TWAIL, as Baxi has noted, close engagement with the "actual human rights struggles" which are enacted by on-the-ground groups or that play out within international bodies should lead us to acquire, exemplify or renew much more complicated and less doctrinaire understandings of the question of essentialism. ${ }^{111}$ Such close engagement will certainly confirm valid insights such as Rajagopal's that the Third World is not moored inflexibly to a fixed geographical space, but is rather constituted by a set of shifting alliances depending on the issue at hand. ${ }^{112}$ It will also confirm that this Third World is best understood as more like what my own teacher, Karin Mickelson, refers to as "a chorus of voices that blend, though not always harmoniously, in attempting to make heard a common set of concerns". ${ }^{113}$ Nevertheless, such close engagement will lead us to renew and sharpen our understanding that, as basically every self-identified TWAILer realizes, more often than not, the voices in the Third World chorus do in fact blend, and as such the "Third World" moniker and the anti-imperial coalition it signifies, need not be abandoned. ${ }^{114}$ States and peoples do selfidentify as part of that coalition, or not, and the coalition might sometimes include or exclude some traditional allies, leading to a more diverse and less traditional geo-political configuration of the Third World. That said, self-identification is heavily influenced by experience, and the sorts of experience of global subjugation that often marks the Third World coalition will often reveal and entail certain kinds of maps - certain "geographies of injustice." 115 In any case, it will also be a mistake for TWAIL theory to become open to being mobilized by those who might

109 See Baxi, The Future of Human Rights, supra note 10 at 142.

110 Ibid at 152-153.

111 Ibid at 152.

112 Balakrishnan Rajagopal, "Locating the Third World in Cultural Geography" (1998-99) Third World Legal Stud 1 [Rajagopal, "Cultural Geography"].

113 See Karin Mickelson, "Rhetoric and Rage: Third World Voices in International Legal Discourse" (1998) 16 Wis Intl L J 353 at 361 [Mickelson, "Rhetoric and Rage"].

114 See Rajagopal, "Cultural Geography”, supra note 113.

115 See Upendra Baxi, "Operation Enduring Freedom: Toward a New International Law and Order?" in Antony Anghie et al, eds, The Third World and International Order: Law, Politics and Globalization (Leiden: Martinus Nijhoff, 2003) at 46. See also Okafor, "Newness," supra note 3. 
seek to undermine the Third World coalition by dwelling too readily and lengthily on the fact of divisions within that group; a fact that is ordinarily about as interesting as suggesting that the Sun rises in the East. ${ }^{116}$

The third conceptual/theoretical promise of close TWAIL engagement is that important TWAIL insights can also be gained by us enacting our dramas of close engagement in ways which pay significantly more attention to what Eslava and Pahuja refer to as the non-typical international legal places which might at first glance appear unrelated to the international. ${ }^{117}$ Clearly, at a minimum, this kind of expanded praxis will in turn enlarge our vistas even further and allow us to see "new" things in these other "material sites [such as in domestic administrative procedures] in which international disciplines are at work" - things that would otherwise be largely screened off from our views. ${ }^{118}$ The accruable insights about the ways in which international law and institutions operate on the quotidian plane would have great potential to enrich TWAIL theory. This is the last example of the ways in which close TWAIL engagement with the relevant bodies/groups can lead us to acquire important insights.

A fourth and somewhat related conceptual/theoretical promise of close TWAIL engagement, especially but not exclusively, with on-the-ground groups, is that the accompanying and ensuing focus on "the everyday" (i.e., the daily lives of people or of institutions) can allow us to more successfully uncover within these environments what has been referred to as subjugated knowledges. ${ }^{119}$ For example, do the various Third World subalterns speak the same or different languages of human rights? ${ }^{120}$ Does it bear any relation to the deeply subjugated and sometimes near-decimated epistemes that characterized pre-colonial and colonial Third World societies? Does it bear any relation to the dominant language of human rights? Is the language of people's rights widely spoken on the African city streets and in its villages, and does this matter in any way? Does this concept of peoples' rights bear any relation to the hegemonic conceptions of international human rights? These kinds of knowledge can be recovered by this kind of focus on the everyday. And more close TWAIL engagement with on-the-ground groups especially those that are rooted in their communities - will help significantly in the processes of uncovering them.

\section{The Perils of Close Engagement with International Institutions or "On-the-Ground" Groups}

\section{A. Strategic/Tactical Perils}

First, one of the greatest strategic/tactical dangers of close TWAIL engagement with international institutions and on-the-ground groups is that we can become consciously or unconsciously implicated in the production of outcomes (intended or unintended) that further undermine the status and conditions of

116 See BS Chimni, "Manifesto", supra note 7 at 50; Upendra Baxi, "What may the "Third World" expect from International Law?" (2006) 27 Third World Q 713 at 714 [Baxi, "What may the 'Third World' Expect?"]; and Obiora Okafor, "Is there a Legitimacy Deficit in International Legal Scholarship and Practice?" (Fall 1997) 13 Intl Insights 91 at 100-101.

117 See Eslava \& Pahuja, supra note 24 at 109.

118 Ibid.

119 See Baxi, Human Rights in a Posthuman World, supra note 100 at 19; and Parmar, supra note 26 at 365.

120 For example, see Makau Mutua, "The Banjul Charter and the African Cultural Fingerprint: An Evaluation of the Language of Duties" (1995) 35 Va J Intl L 339. 
Third World societies and peoples. Gramsci had long theorized the role of the so-called organic intellectual in social relations. ${ }^{121}$ The Gramscian conception of the organic intellectual provides a model of the intellectual schooled in both the theoretical tools of analysis and in practical political struggle and resistance. ${ }^{122}$ All-too-often, these intellectuals help "manufacture consent" to the hegemony of the ruling/dominant classes, groups, peoples or states in the relevant society (domestic or international). ${ }^{123}$ Their efforts are too often central to "the absorption and assimilation of subordinate groups," and have an important legitimization function and effect. ${ }^{124}$ For instance, as Claire Cutler has argued:

In the content of the GATS, a fundamental transformation in the conceptualization of services was required in order to legitimate their commodification. This was achieved by lawyers, government officials, corporate actors and journalists who, as part of an epistemic community, functioned as organic intellectuals. ${ }^{125}$

There is, of course, no inevitability to this. For, the organic intellectual need not always play this kind of anti-subaltern role. S/he can in fact play the exact opposite role within the relevant contexts. Yet, the insidious danger here is that the very act of a TWAILer's close engagement and participation in the discussions and processes that led to an anti-subaltern outcome may serve to legitimize those processes in the eyes of the outside world. Those processes may as a result appear fairer than they actually are. The ways in which the participation of Third World states in hegemonic UN organs like the Security Council lends a measure of legitimacy to that body is indicative here.

A related danger of close TWAIL engagement with the relevant bodies and groups is that we can become habituated over time to seeking the apparent middle ground (howsoever regressively that middle is constructed) in order to reach consensus and just get something done. In some sense, any form of "progress" achieved in the non-academic terrain of praxis can begin to look acceptable enough, however far it remains from the legitimate expectations of TWAILers, and however much it continues to disadvantage and immiserate the vast majority of Third World peoples. I should note that seeking the middle ground in order to get things done is not necessarily and always a bad thing. However, the danger here is that close engagement with those international institutions in which seeking some constructed middle ground is the norm, can function to habituate us to that approach. Here, the term "habituation" is used in the sense in which Pierre Bourdieu theorized his concept of habitus, i.e.. as a "system of [acquiring] dispositions (lasting, acquired schemes of perception, thought and action)."126 This kind of habituation can affect our imaginary and skew our vision of what can be achieved and what

121 See Antonio Gramsci, Selections from the Prison Notebooks of Antonio Gramsci, translated by Quentin Hoare and Geoffrey Nowell Smith, eds (London: Lawrence and Wishart, 1971) at footnote 5; Cutler, supra note 16 at 217; and Mosco, supra note 10 at 36.

122 See Mosco, ibid.

123 Ibid.

124 Cutler, supra note 16 at 217.

125 Ibid.

126 See Pierre Bourdieu, "The Force of Law: Toward a Sociology of the Juridical Field" (1987) 38 Hastings LJ 814. See also Richard Terdiman, "The Force of Law: Toward a Sociology of the Juridical Field -Translator's Introduction" (1987) 38 Hastings Law Journal 805 at 807. 
is possible within the relevant institutional environments. As the horizon of the possible then shrinks before our eyes, so shall we begin to unconsciously self-censor in seeking to enact some form of TWAIL praxis within these bodies. As Bourdieu put it, one of the dangers of habitus is "learning to want what conditions make possible" and "[learning] not to aspire to what is not available." 127 Thus, in seeking to enact a form of TWAIL praxis within these bodies, we need to be alert to the insidious dangers of its possible "training and socialization" effect on us. ${ }^{128}$

The related strategic/tactical danger in becoming habituated to seeking the constructed and often inadequate middle ground while struggling to enact TWAIL praxis within international institutions or other non-academic settings is that we risk becoming the type of mild reformists who fill up the space for critical dissent that Chimni (adapting David Kennedy's work) has long warned against. ${ }^{129}$ Whilst mild reforms are often all that can result from the hardest of our pushes against the entrenched and powerful forces that disadvantage the Third World subaltern, this should never become our main strategic ambition or role.

Another danger that is faced by an international (human rights) law scholar who closely engages with international institutions and on-the-ground groups is that she can more easily place herself in positions where she is forced much more frequently to take simple concrete policy positions on rather complicated issues. All of a sudden, mere "on the one hand" and "on the other hand" kinds of analysis are no longer available to her. For instance, s/he may be forced in human rights or other fora to vote/speak for or against the UN-sanctioned limited intervention in Ghadafi's Libya or intervention within other Third World countries (such as against ISIS in Iraq and Syria). If, as an international (human rights) law intellectual, one votes in favour of such interventions, one almost always legitimizes the maintenance or augmentation of great power hegemony and domination. If one votes against these actions, one will likely be widely regarded as insensitive to the masses of ordinary Third World civilians who are killed or otherwise harmed by powerful elements in these states. Similarly, if one simply argues against the indictment of the sitting President of the Sudan by the ICC or that court's trial of the sitting President of Kenya, on the grounds that - inter alia - its geo-stationary orbit over only the African continent is excessively selective, one strongly risks being widely viewed as an opponent of attempts to end impunity for mass killings on that continent. ${ }^{130}$ But if one supports these ICC trials, one legitimizes that court's clearly excessive and selective focus thus far on the weaker (African) states of the world (a situation that - though not entirely the ICC's fault - is most reminiscent of the colonial era relations between Africa and the international system). ${ }^{131}$ And so, strategic/tactical dangers loom either way. Of course, regarding each of these examples, one option is usually less acceptable than the other from a TWAIL perspective. But the complication is that even seasoned TWAILers can sometimes disagree on

127 See Bourdieu, ibid; and Terdiman, ibid.

128 See Basil Emeka Ugochukwu, "Adjudicating Human Rights in Transitional Contexts: A Nigerian Case Study, 19992009," (PhD Thesis, Osgoode Hall Law School, York University, 2014) [unpublished] at 81.

129 See BS Chimni, "An Outline of a Marxist Course on Public International Law" in Marks, supra note 16 at 54 . See also David Kennedy, "When Renewal Repeats: Thinking against the Box" (2000) 32 NYU J of Intl L and Pol 335 at 372.

130 See Okafor \& Ngwaba, "The International Criminal Court," supra note 33; and Okafor \& Ngwaba, "Between Tunnel Vision", supra note 33. My own personal experience of engaging on this issue with a mass of bright, fervently pro-ICC, African activists at the Dakar meeting referred to earlier in this paper strongly supports this point.

131 Ibid. 
which option better conforms to TWAIL's goals. Thus, if we are to optimize the success of our nonacademic TWAIL praxis, we must sharpen our abilities to navigate these sorts of dangers in as nimble and effective a manner as possible. For instance, in my own experience, reminding the vast majority of human rights activists who tend to hold the ICC in a close, almost non-detachable, loving embrace that the critique of that court's exclusive focus on Africans can be a call for more, and not less, prosecutions around the world, usually blunts their criticisms. Another option for the international (human rights) law scholar who is engaged in such praxis is, of course, to abstain all the time from voting/speaking on such questions, but then s/he might as well stay away completely from close engagement with the relevant bodies/groups.

Lastly, because of our tendency as lawyers to turn to litigation and other legal processes when seeking to effect social change, the international (human rights) law scholar who seeks to enact a form of TWAIL praxis within or in relation to an on-the-ground group may in fact pose a clear and present danger to the grassroots mobilization instincts and praxis of the relevant group. ${ }^{132}$ We may in fact end up diverting and re-channeling their activist energy toward litigation strategies, which (in view of its many limitations as a way of effecting social change) may not always be a wise course to follow. ${ }^{133}$ This would, in turn, become a danger to our own ability to get the most we possibly could out of close engagement with these groups. For, the more these activists become like us (i.e., think like us, deploy our tactics, etc.), the less we are likely to be able to learn from close engagement with them; including in terms of our gaining the otherwise unavailable insights that are generated from their work on the grassroots level.

\section{B. Conceptual/Theoretical Perils}

Only three conceptual/theoretical dangers will be discussed here. First, one of the most important conceptual/theoretical dangers of close TWAIL engagement with international institutions is that the habituation to seeking the middle ground that often comes with the territory can lead us to focus to excess on mild reformist goals, and that this mentality can ultimately seep into our academic work. This would definitely not be a good thing, given our primary roles as academics who are paid to push human society toward the as yet unimagined and unreal, and our pride of place as critical scholars who want to imagine and realize a different and more just world.

The process of engaging closely with the relevant bodies/groups can also lead us to lose our critical edge, and therefore our comparative advantage. It can have this effect by making us become too muddled in the minutiae of the everyday work that the bodies and groups we seek to closely engage with do to have enough time to sit back and reflect as deeply and extensively as we are wont to do as academics. The resulting inability to see the big picture, to see beyond the immediate or the horizons that appear just a little ahead of us, may in turn hamper our abilities to play our proper role as critical intellectuals in as effective a manner as we could.

Lastly, a more widespread TWAIL turn to praxis beyond the academe, and toward close engagement with international institutions and on-the-ground groups, carries with it the theoretical/conceptual risk of

132 See Michael McCann, "Law and Social Movements" in Austin Sarat, ed, Blackwell Companion to Law and Society (Chichester, UK: John Wiley and Sons, 2008) at 513.

133

Ibid. 
succumbing or at least appearing to succumb to those who would, as much as possible, "over-purify" professional disciplines such as ours, by purging them of what they see as way too much theorizing and far too little practical work. We risk giving the impression that all contemplation and the theories that result from such activity are somehow radically divorced from "the real world". While I would strongly urge TWAILers to turn as much as they can, and if they can, toward praxis in various non-academic habitats, I also believe as strongly that we all need to stand on guard against this sort of danger of practical over-purification. This is why when I led the last curriculum reform effort at the Osgoode Hall Law School, my colleagues and I worked very hard to ensure that our then new experiential learning requirement was conceived in a way that required our students to undertake a form of praxis, and not merely some kind of practice. ${ }^{134}$ And this is also why we named that requirement a praxicum, and not a practicum. $^{135}$

\section{CONCLUSION: NO OPEN, SESAME! OR TOWARD THE INTENSIFICATION OF TWAILIAN DRAMATURGY}

In conclusion, it has been shown in this keynote paper that although, if praxis is conceived as the mutual constitution of conception and execution toward the goal of achieving progressive social change, TWAIL itself is already praxis, TWAILers have not - to date - paid as much attention as they ought to the imperative of enacting some form of TWAIL praxis in the non-academic realm (especially within or in relation to international institutions and on-the-ground activist groups). A conceptual/normative framework was then developed with which TWAILers could close this gap in their praxis, and engage more closely with diplomats, high officials, civil servants, activists and so on. This framework was supplemented with insights from the author's experience in undertaking such praxis within and in relation to international institutions and on-the-ground groups. Thereafter, the strategic/tactical as well as theoretical/conceptual promise and perils of such close engagement with these bodies and groups were discussed at some length.

In terms of the overarching argument of the paper, it is best to begin by harkening back to a portion of the poem with which this paper was commenced: one that speaks to the deep wisdom of a lot of African thought. As some of the lines of that poem, written by Chris Okigbo (one of the greatest poets of our time) go:

And he said to the ram: Disarm

And I said:

Except by rooting,

Who could pluck yam tubers from their base? ${ }^{136}$

A key lesson of this poem is that, clearly, TWAIL cannot simply command the ram (the global power matrixes) to "disarm" and have it comply. We cannot just chant "open sesame" and have the gates of

134 See OC Okafor, et al, Report of the Curriculum Reform Working Group, 2010 (on file with author).

135 Ibid.

136 See Okigbo, supra note 1 at 25. 
power open to us so that our TWAIL ideas can march through, settle in, and occupy international/transnational bodies and on-the-ground groups. ${ }^{137}$ As the poet sang, "except by rooting who could pluck yam tubers from their base?"138 While it may not be entirely correct to state, as Marx did in 1845, that "the philosophers have only interpreted the world, in various ways; the point is to change it," ${ }^{\prime 139}$ the point here is that some degree of effective and targeted praxis beyond our comfort zone within the academe seems nevertheless to be required.

Thus, in my own view, TWAILers need to pay even more attention than they have to date, both in our academic contemplation/execution and in our other work, to theorizing and directly or indirectly affecting the ways in which intervention in the internationalist/transnational macro- and micro-dramas which are enacted in various non-academic, political, environments can be used to attain TWAIL's short, medium and long-term goals. As Marx admonishes us:

The chief defect of all hitherto existing materialism - that of Fuerbach included - is that the thing, reality, sensuousness, is conceived only in the form of the object or of contemplation, but not as sensuous human activity, practice, not subjectively. Hence, in contradistinction to materialism, the active side was developed abstractly by idealism which, of course, does not know real, sensuous activity as such. ${ }^{140}$

While this turn toward what Marx refers to as "sensuous human activity" and what we would rather describe as the enactment of TWAIL praxis beyond the academe, will have merit in and of itself as a way of reinforcing our strategic craft and breathing life into our own alternative imaginaries of global order, as has been shown, it will also enrich our theoretical craft itself.

This will not necessarily mean a wholesale TWAIL turn to international institutions or on-the-ground activist groups, in the sense of most of us becoming embedded within or otherwise closely engaging those bodies. The dangers of close engagement that have been outlined in this paper, and the need to retain the "external viewpoint", suggest otherwise. What is more, we cannot be impervious to the fact that our positions as scholars, as members of the academe allows us a space that is rather unique from which to think and speak more critically about these international institutions and on-the-ground activist groups. What it does mean, however, is that while being as reflexive as possible, as many of us as are interested must strive, as best we can, to engage more closely with these bodies/groups, including in the mental as well as physical, locational, sense. To do this effectively, nothing less than the intensification of TWAILian dramaturgy is required.

137 See "Ali Baba and the Forty Thieves" in DL Ashman, ed, 1000 Nights (2013), online:

$<$ http://www.pitt.edu/ dash/alibaba.html .

138 See Okigbo, supra note 1 at 25.

139 See Karl Marx, "Ludwing Fuerbach and the End of Classical German Philosophy: Appendix" in Marx/Engels: Selected Works (Moscow: Progress Publishers, 1969) at 15.

$140 \quad$ Ibid at 13. 